\title{
Firm Performance, Top Management Compensation, and Risk Preference: A Story of Indonesian Firms
}

\author{
EVY RAHMAN UTAMI* \\ Universitas Muhammadiyah Yogyakarta \\ INDRA WIJAYA KUSUMA \\ Universitas Gadjah Mada
}

\begin{abstract}
The issue of conflict of interests between shareholders and managers is interesting and widely examined. Compensation is often used to align the interests of managers with those of shareholders. This study aims, first, to show empirical evidence of the relationship between a company's performance and the manager's compensation. In addition, this study also examines the impact of risk preference on that relationship. The sample for this study of manufacturing companies listed in the Indonesian Stock Exchange (BEI) from 2008 to 2013. Data were obtained from annual reports, financial statements, and BvD Osiris. Regression analysis was employed to test the hypotheses. The results show that compensation is related more to accounting performance than to market performance. The compensation also had an impact on future accounting performance, but not on future market performance. However, contrary to the expectation, risk preference does not strengthen the relationship between future compensation and future performance. After splitting the sample into three categories, the compensation can motivate managers to increase accounting performance only for companies with better performance.
\end{abstract}

Keywords: Compensation, Accounting Performance, Market Performance, Risk Preference.

Abstrak: Masalah konflik kepentingan antara pemegang saham dan manajer menarik dan dikaji secara luas. Kompensasi sering digunakan untuk menyelaraskan kepentingan manajer dengan kepentingan pemegang saham. Penelitian ini bertujuan, pertama, untuk menunjukkan bukti empiris tentang hubungan antara kinerja perusahaan dan kompensasi manajer. Selain itu, penelitian ini juga meneliti dampak preferensi risiko pada hubungan itu. Sampel untuk penelitian ini dari perusahaan manufaktur yang terdaftar di Bursa Efek Indonesia (BEI) untuk periode 2008 hingga 2013. Data diperoleh dari laporan tahunan, laporan keuangan, dan BvD Osiris. Analisis regresi digunakan untuk menguji hipotesis. Hasil menunjukkan bahwa kompensasi lebih terkait dengan kinerja akuntansi daripada kinerja pasar. Kompensasi juga berdampak pada kinerja akuntansi masa depan, tetapi tidak pada kinerja pasar di masa depan. Namun, bertentangan dengan ekspektasi, preferensi risiko tidak memperkuat hubungan antara kompensasi di masa depan dan kinerja masa depan. Setelah membagi sampel menjadi tiga kategori, kompensasi dapat memotivasi manajer 
The Indonesian Journal of Accounting Research - May, Vol. 22, No.2, 2019

untuk meningkatkan kinerja akuntansi hanya untuk perusahaan dengan kinerja yang lebih baik.

Kata kunci: Kompensasi, Kinerja Akuntansi, Kinerja Pasar, Risk Preference.

\section{Introduction}

A survey of Indonesian Central Bank (Bank Indonesia) shows that the remuneration of the board of directors of the banking industry in Indonesia was higher than that in Thailand, Malaysia, or the Philippines (Wiyanti, 2013). The survey shows that CEOs from Indonesia have the highest remuneration, while CEOs from the Philippines have the lowest. This phenomenon drives the Indonesian government to regulate the disclosure of compensation. Managers' compensation has been a concern not only for the academician but also for standard setters and the society at large in recent years (Gigliotti, 2013). While the issue of compensation has been studied extensively, the issue shown in the studies is mostly to develop within the U.S. framework. Meanwhile, in Asia, the compensation issue is still relatively neglected because of data availability problems (Kato, Kim, \& Lee, 2007). In Indonesia, compensation issues arose with the Company Act No. 40 (2007), in which the Securities Exchange Commission (S.E.C.) set compensation disclosures widely.

This study aims to show the empirical evidence of the relationship between corporate performance, compensation, and risk preference in the period following the issuance of the Company Act No. 40 of 2007. The relationship between risk and return shows the proportional relationship. The higher the risk, the higher the expected return. Shareholders tend to prefer managers who are willing to take risks (risk taker) because the risk-taking behaviors would affect the company's performance and thus increasing shareholder return (Devers et al. (2008). Devers, Cannella, Reilly, \& Yoder (2007) explain two theories used in the research of compensation; these theories are: (1) payto-performance approaches typically drawn from motivational theory in psychology and (2) performance-to-pay approach grounded in agency theory. Agency scholars suggest that compensation pay aligns the interest of managers and those of the shareholders by 
curbing executive opportunism and discouraging risk aversion (Devers, Cannella, Reilly, \& Yoder, 2007). Besides, the majority of compensation studies and practices are grounded in positive agency theory suggesting that since compensation ties pay to firm outcomes, incentive pay will reduce the threat of executive opportunism by motivating executives to engage in actions that maximize firm performance (Devers et al. 2007). Researchers included a risk preference that refers to the theory developed by Wiseman \& Gomez-Mejia (1998), Devers et al., (2007), and Nyberg et al. (2010) to investigate whether compensation aligns preferences and actions between managers and shareholders to produce better corporate performance. Alignment occurs when manager preference approaches the shareholders' preference. The shareholders prefer managers who are risk-takers (make research and development (R\&D) decision) because they potentially will decide to increase shareholder returns. A high return will reflect high performance. Agency theory predicts a conflict of interest between the shareholders and the managers (Jensen \& Murphy, 1990a). In this theory, managers seek to maximize personal gain and do not consider the interests of shareholders. The condition is overcome by aligning the interests of owners and managers through compensation contracts (Jensen \& Murphy, 1990a). Nyberg et al. (2010) describe the alignment of incentives as involving two components, namely, financial alignment and preference and action alignments.

Several factors motivate this study. First, previous studies examined the relationship between performance and compensation (Conyon \& $\mathrm{He}, 2012$; Gunasekaragea \& Wilkinson, 2002; Kato et al., 2007; Kato \& Kubo, 2006; Merhebi, Pattenden, Swan, \& Zhou, 2006; Sun, Wei, \& Huang, 2013; Xiao, He, Lin, \& Elkins, 2013; Yang, Dolar, \& Mo, 2014), but few studies that examined the effect of compensation on future performance (Banker, Huang, \& Plehn-Dujowich, 2013). Second, research conducted by (Devers, Holcomb, \& Cannella, 2006) posited that risktaking behaviors are related to the relationship between compensation and company performance. Previous studies' results are inconsistent. One potential explanation is that the level of risk preference among top management teams differs. This study uses risk preference as a moderating variable. This study differs from previous ones in several 
aspects. First, previous studies only used CEO compensation, while this study uses the top management team's (TMT) cash compensation. In Indonesia, TMT was defined as the board of commissioners and board of directors. Indonesia adopts a two-tier system: splitting between those who run the company (board of directors) and those who conduct surveillance (board of commissioner).

Hambrick \& Mason (1984) were the first scholars to investigate the theory of the "Upper Echelons," which refers to the organization as a reflection of its top managers. They predict that the election strategy and organizational performance can be predicted from the background and characteristics of the management team. Hambrick (2007); Naranjo-Gil et al. (2012) explain that a collectively formed top management will achieve a higher performance than the team with an individualist orientation. Nguyen (2012) mentions that the top management includes the CEO, CFO, and other senior managers to countries with a one-tier system. Second, Devers et al. (2006) measure risk preference using the number of company acquisitions, whereas this study uses $R \& D$ costs (C. E Devers et al., 2008; Guay, 1999; Miller \& Bromiley, 1990). Miller \& Bromiley (1990) explain nine proxies to measure risk. One of them is research and development costs (R\&D). This study measures risk aversion using $R \& D$ because of data availability and the company type. Third, previous studies conducted in Indonesia were related to compensation in the banking industry (Sugiri, Febrianto, \& Kresnawati, 2016), while this study uses manufacturing companies listed in the Indonesia Stock Exchange from 2008 to 2013. This study also performs additional testing on the relationship between compensation and future performance based on several categories of companies (great, good, and poor).

This study contributes significantly to the academia and practice. It confirms the behavioral agency model by adding empirical evidence on the relationship between performance and the compensation, and that between compensation and future performance. The study also provides valuable information to standard setters on the guidance for compensation in the company. This information is essential given that compensation rules in 2015 have been in force in the ASEAN Economic Community (A.E.C.). This A.E.C. attracts resource movement to or from Indonesia, especially of 
professional staff accountants. This study is for reference in designing compensation schemes and presenting accounting data used to evaluate performance and compensation.

\section{Hypothesis Development}

\subsection{Company Performance with Compensation}

Result of previous studies related to the performance and compensation have been inconsistent. There are more than 300 studies conducted in this regard for more than 70 years (Barkema \& Gomes-Mejia, 1998). The agency theory predicts that contractual compensation should be tied to the performance in order to address the moral hazard associated with information asymmetry problem between shareholders and managers (Conyon \& He, 2012). The study generally describes compensation as a reward for previous performance (Fama, 1980). Researchers often see these relationships as an indicator of the relationship between performance and compensation.

The concept of sensitivity in the relationship between performance between and compensation is the association between the manager's wealth changes and the shareholder's wealth changes (Jensen \& Murphy, 1990b). Jensen \& Murphy (1990b) investigated the sensitivity of the increase in performance with compensation paid to the CEOs of 250 major companies in the United States for 15 years. Their results showed that the average total CEO compensation rises $\$ 3.25$ for every $\$ 1,000$ increase in shareholder wealth.

Research related to the relationship between performance and compensation showed no association. Jensen \& Murphy (1990b) and Rost \& Osteroh (2009) found that performance was not related to compensation. One of the possible explanations is that managers do not necessarily work better in the use of stock compensation because it has long term impact, but some other studies show a positive relationship between the two variables (Banker et al., 2013; Conyon \& He, 2012; Ghosh \& Aggarwal, 2011; Kato $\&$ Kubo, 2006; Merhebi et al., 2006; Sun et al., 2013). Logically, the manager will be compensated based on their performance (Sugiri et al., 2016). Managers with a high 
performance get proper compensation for their achievement in raising the company's performance. Therefore, the first hypothesis is proposed as follows:

H1. Company performance is positively related to the compensation of the top management team.

\subsection{Impact of Compensation on the Company's Future Performance}

Studies related to the compensation issue have been widely discussed, not only focused on the relationship between performance and compensation, but also the relationship between compensation and company future performance. The researchers examined the relationship of compensation with performance using the concept of compensation as a motivational tool (Devers et al., 2007).

Devers et al. (2007) explained that there were several reasons for the lack of attention to the alignment between the compensation model for future performance and the performance model for compensation. First, the model is quite complex and requires a data sequence. Second, the theories for both models are different and are not always consistent. The compensation model for performance utilizes a motivational theory in psychology, while the performance for the compensation model is always based on agency theory. Both theories are not always met because they have different basic assumptions, different variables, and different research questions. However, some studies on the relationship between performance and compensation and the relationship between compensation and future performance are important if one wants to understand compensation.

Banker et al. (2013) showed that the current salary has a positive relationship with future performance, while the bonus is not related to future performance. Lewellen et al. (1992) showed a positive association between performance and compensation and described the design of compensation to contribute to the reduction of agency costs in large corporations. Additionally, Cordeiro et al. (2007) showed that compensation was positively related to firm performance. The fundamental purpose of compensation is to motivate managers towards improving business performance. Compensation is used not only as a tool to motivate them to work longer on the job, but also to encourage managers to perform better in their tasks (Sprinkle, 2000). Thus, if the above theory is 
valid, then compensation can motivate managers to improve the company's future performance. Therefore, the second hypothesis is proposed as follows:

H2. Top management team compensation is positively related to the company's future performance.

\subsection{Compensation, Risk Preferences and Corporate Performance in the Future}

Devers et al. (2007) organizing executive compensation studies into two categories, namely: (1) relationship between pay and performance and (2) relationship between the pay and behaviors. One of the discussion subjects in the category of the relations hip between pay and behaviors is risk preference alignment. They explain that the preference for risk is aligned to the assumption that the manager will act risky, and is consistent with the decision of shareholders.

Prospect theory explains that the point of individual risk preference may change depending on the preference level of income (Aaron, Harris, Mcdowell, \& Cline, 2014). The differences in the compensation package are a different prospect that can be selected by the manager. Compensation has an important role in risk acceptance. Besides, Sawers et al. (2011) state that the behavioral agency model (BAM) combines the agency theory and the prospect theory in developing an understanding of the risktaking behavior of managers. Wiseman \& Gomez-Mejia (1998) examine the ability of compensation to increase the integration of risk preferences, and also investigate the extent to which compensation can increase risk-taking behavior among the managers.

Nyberg et al. (2010) describe the alignment of incentives based on two components: financial alignment and preference and action alignment. The behavior of a manager tends to be risk-averse, whereby the majority of private wealth is invested in the company, and risk diversification is explicitly forbidden (Jensen \& Murphy, 1990b). On the other hand, shareholders tend to be risk-neutral by diversifying their wealth in the company. Compensation is a tool for motivating managers from a risk-averse position to a risk-taker position. Therefore, it will increase performance. The implicit assumption in many studies shows a fairly strong financial alignment, followed by the alignment of preferences and actions (Nyberg et al., 2010). Gray \& Cannella (1997) 
concluded that managers and shareholders face very different risks. These risks are not always in harmony with the context of the compensation, which is closely connected with the reward and performance. They also found that the compensation arrangement does not necessarily combine salary and performance or align with the risk preferences of managers and shareholders.

On the other hand, Gray \& Cannella (1997) investigated the role of risk in manager compensation. They rearrange the compensation used to mitigate the agency problem as behavioral risk preferences and provide compensation for long-term performance. They predict that company managers in high-risk conditions should receive higher compensation. Evidence suggests that if companies in high-risk situations are paid low compensation, they find it difficult to attract and retain executives. Meanwhile, Belanes \& Hachana (2010) show that the company's founder and the majority of shareholders influence managerial risk-taking, which confirms the predictions of agency theory. The investors want managers to pursue its growth strategy and look for opportunities to improve the company's performance and competitiveness.

Risk is defined as the extent to which uncertainty is related to the results (Sitkin \& Pablo, 1992). The definition of risk contains three key dimensions, namely, outcomes uncertainty, outcome expectations, and potential outcomes. Outcome uncertainty is the risk associated with the uncertainty of the results, which is described by the variability of results, lack of knowledge about the distribution of potential outcomes, and the inability to control the achievement. Outcome expectations related to decisions and risk indicate that a positive return leads to the framing of a different decision in decisionmaking behavior. Outcome potential is a considerable choice of potential consequences for decisions in the face of threats or inherent opportunities. This study focuses on outcomes expectations because of measuring risk preference using the cost of $R \& D$ (Devers et al., 2008; Guay, 1999; Miller \& Bromiley, 1990). Wiseman \& Gomez-Mejia (1998) explain that the difference in the manager compensation preference implies that the contract could have different effects. This implies performance.

Devers et al. (2006) examine the alignment of objectives and the risks inherent in the alignment of interests separately. The results show a positive relationship between 
the level of aggregate long-term incentives for the top management and shareholder returns. In addition, they also provide empirical evidence that the long-term compensation for the top management is associated with risk preference. Alignment occurs when the manager's preference approaches the shareholder's preference. The shareholders prefer risk-taking managers because they will make a potential decision to increase shareholder returns. The manager who makes the $R \& D$ decision shows the managers' risk-taking behavior. The greater the costs of $\mathrm{R} \& \mathrm{D}$, the more willing be managers are to take risks and have the expectation of generating high returns. A high return reflects a high performance. Managers who take risks (risk takers) when the compensation is high will be motivated to produce better performance in the future. Based on the above arguments, the researchers propose a hypothesis as follows:

H3. Risk-taking preference strengthens the relationship between Top Management Team compensation and the company's performance in the future.

\section{Research Methods}

The study sample comprised of manufacturing companies in Indonesia listed in the Indonesian Stock Exchange in the period 2008 to 2013. Companies in the manufacturing industry were used as a sample because different types of industries have different compensation disclosures principles. Companies are selected through purposive sampling, with the following criteria: (a) manufacturing companies that published annual report data and the financial reports for the period 2008-2013, (b) companies that disclosed top management compensation (board of directors and board of commissioners), and (c) the companies that have relevant data.

\subsection{Variable Measurement}

Top management compensation in the form of cash compensation consists of compensation for the board of directors and the board of commissioners. Cash compensation is the amount of salary and annual bonus (Cheng, 2004). In Indonesia, the compensation data includes the salary, benefits, and bonuses or gratification in the form of cash. The data was collected manually from the annual reports on corporate governance or financial statements from the notes to the Financial Statements. 


\section{Compensation $=$ Salary + Benefits + Bonuses (Gratification)}

Company performance uses a proxy-based on accounting and the markets (Conyon $\& \mathrm{He}, 2012$ ). Accounting measurements were made using a return on assets (Grace, 2004; Kato \& Kubo, 2006), and the market measurement was by using the stock return (Conyon \& He, 2012; Parthasarathy, Menon, \& Bhattacherjee, 2006). The data was obtained from BvD Osiris and Yahoo Finance.

\section{ROA = Net Income $/$ Total Assets \\ Return $=\left(\mathbf{P}_{\mathrm{t}}-\mathbf{P}_{\mathrm{t}-1}\right) / \mathbf{P}_{\mathrm{t}-1}$}

where:

$\mathrm{P}_{\mathrm{t}}=$ Stock price at the end period $\mathrm{t}$

$\mathrm{P}_{\mathrm{t}-1}=$ Stock price at the end period $\mathrm{t}-1$

Risk preference is the tendency to taking risks associated with the company. The costs of R\&D are used to measure risk preference (Devers et al., 2008; Guay, 1999; Miller \& Bromiley, 1990). Decision made by the managers about R\&D reflects the extent to which managers dare to invest in uncertainty and potentially on the value, whereby this act can strategically increase shareholder wealth (Miller \& Bromiley, 1990). The data R\&D costs were taken from BVD Osiris and the company's financial statements. The costs were only found (disclosed) in the manufacturing sector.

Two control variables were used, namely firm size (Belanes \& Hachana, 2010; Xiao et al., 2013) and leverage (Haron \& Akhtaruddin, 2013). The firm size was measured by the logarithm of total assets, while leverage was used to measure the funding decisions of the firm. Managers of bigger companies were expected to get higher pay compares to those of smaller companies because of differences in the level of the task and decision complexity that must be completed (Doucouliagos, Haman, \& Askary, 2007). The higher the leverage, the greater the risk level of the company. Leverage was measured using total debt divided by the total assets. The data used as a proxy for the control variable was obtained from BVD Osiris and the company's financial statements. 


\section{Leverage $=$ Total Debt $/$ Total Assets}

\subsection{Research Model}

This study uses regression analysis to analyze the relationship between the performance of the company, top management compensation, and risk preferences. The regression equations are as follows.

Regression equation hypothesis 1 :

$\operatorname{Comp}_{i, t}=\alpha+\beta_{1} \operatorname{Perf}_{i, t}+\beta_{2} S_{i, t}+\beta_{3} L V_{i, t}+e$

Regression equation for hypotheses 2 and 3:

Perf $_{i, t+1}=\alpha+\beta_{1} \operatorname{Comp}_{i, t}+\beta_{2} \mathrm{SZ}_{i, t}+\beta_{3} \mathbf{L V} V_{i, t}+\mathrm{e}$

For testing hypothesis 3, the same regression is performed under two split samples based on the risk preference.

where:

$\operatorname{Perf}_{i, t+1} \quad=$ Performance $\mathrm{i}$ for time $\mathrm{t}+1$

Perf $_{\mathrm{i}, \mathrm{t}} \quad=$ Performance $\mathrm{i}$ for time $\mathrm{t}$

Comp $_{i, t} \quad=$ Top Management Compensation from country $\mathrm{i}$ for time $\mathrm{t}$

$\mathrm{SZ}_{i, t} \quad=$ Firm size from country $\mathrm{i}$ for time $\mathrm{t}$

$\mathrm{LV}_{i, t} \quad=$ Leverage from country $\mathrm{i}$ for time $\mathrm{t}$

\subsection{Additional Test}

An additional test was conducted by providing empirical evidence for the relationship between top management compensation and the company's performance based on the company category (Murphy, 1998). Companies were categorized into three categories: great, good, and poor. The company's performance regarding both the ROA and return are sorted (separately) from the highest to the lowest and then divided into three as follows: $25 \%$ for top performance (great), $50 \%$ performance of the middle (good), and $25 \%$ of lowest performance (poor). 


\section{Result and Discussions}

The total sample for each test model is different. Table 1 presents the sample selection procedure is as follows:

Table 1

Sample Selection

\begin{tabular}{lcccc}
\multicolumn{1}{c}{ Criteria } & \multicolumn{2}{c}{ Hypothesis 1 } & \multicolumn{2}{c}{$\begin{array}{c}\text { Hypothesis 2 } \\
\text { (Full Sample) }\end{array}$} \\
& Return & ROA & Return & ROA \\
\hline $\begin{array}{l}\text { The number of samples } \\
\text { manufacturing company period }\end{array}$ & 810 & 810 & 675 & 675 \\
\hline $\begin{array}{l}\text { Com-2013 } \\
\text { Companies with incomplete data }\end{array}$ & 208 & 188 & 177 & 172 \\
\hline $\begin{array}{l}\text { Samples that ful fill the Purposive } \\
\text { Sampling }\end{array}$ & 602 & 622 & 498 & 503 \\
\hline Outlier* & 30 & 31 & 9 & 20 \\
\hline Final sample & 572 & 591 & 489 & 483 \\
\hline
\end{tabular}

* Outliers are deleted based on ZScore (below and above -3 and +3 removed from the sample).

Table 2

Sample Selection Based on the Classification Testing

\begin{tabular}{lcccc}
\hline \multirow{2}{*}{ Criteria } & \multicolumn{2}{c}{ R\&D: High } & \multicolumn{2}{c}{ R\&D: Low } \\
& Return & ROA & Return & ROA \\
\hline Company disclose R\&D & 38 & 40 & 38 & 38 \\
\hline Outlier & 1 & 0 & 1 & 0 \\
\hline Final sample & 37 & 40 & 37 & 38 \\
\hline
\end{tabular}

Table 2 presents the sample selection based on classification testing. The sample "R\&D: High" and sample "R\&D: Low" are classified based on the median of research and development (R\&D).

\subsection{Testing the Relationship Between Performance and Compensation}

Table 3 presents an overview of the descriptive statistics of each variable for the first hypothesis. The values of mean and median for all variables, whether the returns or ROA measures the performance, do not differ significantly. The mean and median are not much different, indicating that the data are normally distributed. The standard deviation of all variables except that measured by the ROA is relatively low. 
Table 3

Descriptive Statistics on the Compensation Performance Testing

\begin{tabular}{llllll}
\hline \multicolumn{1}{c}{ Variable } & Min & Max & Mean & Median & Std. Dev. \\
\hline Performance (Return) & & & & & \\
Ln_Compensation & 12.637 & 19.780 & 15.682 & 15.645 & 1.304 \\
Performance (return) & -0.950 & 9.926 & 0.262 & 0.343 & 0.912 \\
Log_TA & 17.680 & 25.211 & 20.997 & 20.837 & 1.503 \\
Leverage & 0.000 & 3.342 & 0.557 & 0.476 & 0.477 \\
$\begin{array}{l}\text { Performance (ROA) } \\
\text { Ln_Compensation }\end{array}$ & 12.637 & 19.780 & 15.640 & 15.624 & 1.299 \\
Performance (ROA) & -32.950 & 56.920 & 7.972 & 6.380 & 11.560 \\
Log_TA & 17.703 & 25.211 & 20.977 & 20.829 & 1.482 \\
Leverage & 0.000 & 3.342 & 0.539 & 0.473 & 0.447 \\
\hline
\end{tabular}

Table 4 shows the results of regression for the first hypothesis for both the market and accounting performances.

Table 4

Regression Analysis of the Compensation Performance Testing

\begin{tabular}{lcccccc}
\hline \multicolumn{1}{c}{ Variable } & Coef & $\begin{array}{c}\text { Return } \\
\mathbf{t}\end{array}$ & Sig & Coef & $\begin{array}{c}\text { ROA } \\
\mathbf{t}\end{array}$ & Sig \\
\hline Constanta & 1.659 & 3.524 & 0.000 & 2.271 & 5.165 & 0.000 \\
Performance & 0.017 & 0.481 & 0.631 & 0.020 & 6.362 & $0.000^{*}$ \\
Log_TA & 0.675 & 30.589 & $0.000^{*}$ & 0.636 & 31.012 & $0.000^{*}$ \\
Leverage & -0.292 & -4.200 & $0.000^{*}$ & -0.240 & -3.203 & $0.001^{*}$ \\
\hline
\end{tabular}

$*$ Significant at alpha 5\%

The first hypothesis states that compensation is positively related to performance. For market performance, the return is not significant (sig=0.631). This result suggests that market performance is not positively related to compensation. This result fails to support the first hypothesis. For the accounting performance, the return is significant (sig=0.000). This result shows that consistent with the hypothesis, accounting performance has a positive and significant relationship with the compensation.

Top management compensation in manufacturing companies in Indonesia depends more on accounting performance rather than market performance, particularly evidenced by the accounting performance measured by ROA. The higher the ROA, the more managers effectively use the assets for the benefit of shareholders (Haniffa \& Hudaib, 2006). High ROA also reflects the use of assets effectively in serving the 
economic interests of shareholders (Ibrahim \& Samad, 2011). A company that performs well regarding in the ROA indicates managerial success in the firm.

The results of these studies suggest a way to align the interests of top management and shareholders by increasing work motivation through accounting performance. Managers are paid more when they work to improve the accounting performance of the company as an internal input rather than to increase the stock price (Conyon \& $\mathrm{He}$, 2012). This result supports the study by Conyon \& He (2012), which concluded that the accounting performance is stronger than market performance. However, Conyon \& $\mathrm{He}$ (2012) proved that both measurement models (return and ROA) show significant results. This study is important for top management in making a business plan. Companies prioritize accounting performance over the market performance, particularly concerning the compensation received.

The relationship between market performance (return) and top management compensation is not supported. Market performance is weak and unsupported because it is influenced by economic and political factors (Conyon \& He, 2012). The top management is more difficult to use for controlling and regulating market performance within a broad scope and with the involvement of external parties. The market performance will be influenced by many parties (government, investors, the economic environment both domestically and abroad), so the manager is not able to regulate the conditions as desired. This study supports research by Kato \& Kubo (2006) and Merhebi et al. (2006). The results (H1) support the agency theory only on performance as measured by accounting performance (ROA).

Company size as a control variable for both models of performance measurement, namely return and ROA, is significant $(\mathrm{sig}=0.000)$ and has a positive coefficient. The total asset is positively related to top management compensation. Companies that have big assets, the company, compensate higher for the manager. Leverage as control variables in both models are also significant (sig=0.000 and 0.001) and possess a negative coefficient. 
4.2. Testing on the Effect of Compensation on Future Performance and Risk Preferences

Table 5 presents the overall descriptive statistics for the variables. As expected, Table 5 is similar to Table 3 , with the only difference is the number of firms used.

Table 5

Descriptive Statistics Tests Compensation to Future Performance

\begin{tabular}{lrrrrr}
\hline \multicolumn{1}{c}{ Variable } & \multicolumn{1}{c}{ Min } & \multicolumn{1}{c}{ Max } & Mean & Median & Std. Dev. \\
\hline \multicolumn{5}{c}{ Performance (FReturn) } \\
Ln_Compensation & 12.339 & 20.606 & 15.579 & 15.589 & 1.324 \\
Performance (FReturn) & -0.923 & 2.817 & 0.241 & 0.069 & 0.611 \\
Log_TA & 17.680 & 25.929 & 20.919 & 20.795 & 1.503 \\
Leverage & 0.000 & 144.162 & 0.850 & 0.474 & 6.512 \\
\multicolumn{5}{c}{ Performance (FROA) } \\
Ln_Compensation & 12.339 & 19.584 & 15.540 & 15.550 & 1.274 \\
Performance (FROA) & -30.780 & 47.360 & 8.043 & 6.810 & 10.333 \\
Log_TA & 17.680 & 24.887 & 20.868 & 20.737 & 1.452 \\
Leverage & 0.000 & 3.210 & 0.550 & 0.472 & 0.468 \\
\hline
\end{tabular}

Table 6 presents the regression results of compensation and future performance. Future performance is proxied by market performance (return) and accounting performance (ROA).

Table 6

Regression Analysis Testing Compensation and Future Performance

\begin{tabular}{lcccccc}
\hline \multicolumn{1}{c}{ Variable } & \multicolumn{3}{c}{ FReturn } & FROA & \\
& Coef & T & Sig & Coef & t & Sig \\
\hline Constanta & 0.319 & 0.815 & 0.415 & -5.525 & -0.786 & 0.432 \\
Ln_Compensation & -0.007 & -0.242 & 0.809 & 2.087 & 4.284 & $0.000^{*}$ \\
Log_TA & 0.001 & 0.053 & 0.958 & -0.775 & -1.817 & 0.070 \\
Leverage & 0.009 & 2.171 & $0.030^{*}$ & -4.893 & -2.976 & $0.003^{*}$ \\
\hline
\end{tabular}

* Significant at alpha $5 \%$

For market performance, compensation is not significant $(\mathrm{p}=0.809)$. These results suggest that top management compensation is not positively related to return. This result fails to support the second hypothesis. However, for accounting performance, the impact of compensation is significant $(\mathrm{p}=0.000)$. It shows that compensation is positively related to the ROA, thus supporting the second hypothesis. 
Compensation for the manager can motivate managers to work better for future accounting performance. A company's accounting performance is governed by the manager and restricted by standards set by the profession so that the performance is influenced by accounting practices, for example, the methods used for the assessment of tangible and intangible assets (Kapopoulos \& Lazaretou, 2007). Accounting performance is easier planned than market performance because it involves only internal parties, while market performance is a product of various parties.

The relationship between compensation and accounting performance in the future can align the interests of managers and shareholders. Managers get a high reward and are motivated to create a good future performance. Conversely, it has not been proven that the top management compensation can motivate managers to improve market performance in the future. Measurements of the performance-based market are characterized by various aspects in the future and reflect future expectations of the shareholders (Ganguli \& Agrawal, 2015; Shan \& McIver, 2011; Wahla, Shah, \& Hussain, 2012). Market performance can reflect future opportunities that come from outside factors for managerial decisions and are indicated by the company level (Shan \& McIver, 2011). More factors affect market performance than accounting performance. These factors make managers not keen to focus on the market's performance in relation to the compensation received. The result (H2) supports the explanation given by Devers et al., (2007) that compensation can motivate managers to work better as reflected by future company performance based on accounting performance (ROA).

Control variables for company size are not related to the company's performance in the future for both models. However, leverage is positively associated with the future performance of the market. On the other hand, the leverage in the corporate performance measurement model using accounting performance (ROA) is negatively associated with performance in the future.

Table 7 and Table 8 present the descriptive statistics split samples. The sample is divided based on the magnitude of R\&D: High and Low. The standard deviation of all variables on split samples in which the performance measurement was done using 
returns, showed small standard deviations. The relatively small standard deviations indicate individual data points close to the average. On the other hand, the standard deviation of performance variables measured by ROA shows a high value (12.176 and 9.736) for R\&D High and R\&D Low, respectively. The mean and median for Table 7 and Table 8 show that the values of all variables are relatively similar.

Table 7

Descriptive Statistics Split Sample (Performance=Return)

\begin{tabular}{lllrrr}
\hline \multicolumn{1}{c}{ Variable } & Min & Max & Mean & Median & Std. Dev. \\
\hline & & "R\&D High" & & & \\
Ln_Compensation & 14.039 & 18.385 & 16.435 & 16.916 & 1.481 \\
Performance (FReturn) & -0.697 & 1.462 & 0.268 & 0.212 & 0.474 \\
Log_TA & 18.420 & 23.990 & 21.735 & 22.313 & 1.623 \\
Leverage & 0.058 & 0.799 & 0.332 & 0.302 & 0.177 \\
& & "R\&D Low" & & & \\
Ln_Compensation & 12.339 & 18.039 & 15.307 & 14.655 & 1.504 \\
Performance (FReturn) & -0.590 & 2.150 & 0.260 & 0.164 & 0.552 \\
Log_TA & 18.407 & 24.003 & 21.058 & 20.656 & 1.428 \\
Leverage & 0.027 & 0.825 & 0.368 & 0.340 & 0.212 \\
\hline
\end{tabular}

Table 8

Descriptive Statistics Split Sample (Performance=ROA)

\begin{tabular}{lrlrrr}
\hline \multicolumn{1}{c}{ Variable } & \multicolumn{1}{c}{ Min } & \multicolumn{1}{c}{ Max } & Mean & Median & Std. Dev. \\
\hline & \multicolumn{5}{c}{ "R\&D High" } \\
Ln_Compensation & 14.039 & 18.385 & 16.501 & 16.946 & 1.444 \\
Performance (FROA) & -14.240 & 52.950 & 16.786 & 15.715 & 12.176 \\
Log_TA & 18.420 & 23.991 & 21.777 & 22.357 & 1.592 \\
Leverage & 0.058 & 0.799 & 0.319 & 0.301 & 0.176 \\
& "R\&D Low" & & & \\
Ln_Compensation & 12.339 & 18.039 & 15.265 & 14.688 & 1.431 \\
Performance (FROA) & -11.960 & 35.940 & 9.510 & 7.355 & 9.736 \\
Log_TA & 18.407 & 24.003 & 20.990 & 20.517 & 1.387 \\
Leverage & 0.027 & 0.914 & 0.398 & 0.353 & 0.226 \\
\hline
\end{tabular}

Table 9 and Table 10 present the results of the regression analysis of split samples for performance based on return and ROA. 
Table 9

Regression Analysis of Split Samples (Performance=Return)

\begin{tabular}{lcccccc}
\hline \multicolumn{1}{c}{ Variable } & \multicolumn{3}{c}{$\begin{array}{c}\text { FReturn } \\
\text { "R\&D: High" }\end{array}$} & \multicolumn{3}{c}{ FReturn } \\
& Coef & t & Sig & Coef & T & Sig \\
\hline Constanta & 0.892 & 0.827 & 0.414 & 2.115 & 1.459 & 0.154 \\
Ln_Compensation & -0.158 & -1.452 & 0.156 & -0.139 & -1.135 & 0.265 \\
Log_TA & 0.092 & 0.927 & 0.360 & 0.013 & 0.105 & 0.917 \\
Leverage & -0.112 & -0.239 & 0.812 & -0.038 & 0.088 & 0.930 \\
\hline
\end{tabular}

Table 10

Regression Analysis of Split Samples (Performance=ROA)

\begin{tabular}{lcccccc}
\hline \multirow{1}{*}{ Variable } & \multicolumn{2}{c}{ FROA } & \multicolumn{3}{c}{ FROA } \\
& "R\&D: High" & & \multicolumn{3}{c}{ "R\&D: Low" } & Toef \\
& t & Sig & Coef & T & Sig \\
\hline Constanta & -56.281 & -3.732 & 0.000 & -32.913 & -1.539 & 0.133 \\
Ln_Compensation & 1.647 & 0.650 & 0.520 & -2.113 & -1.574 & 0.125 \\
Log_TA & 2.597 & 1.177 & 0.247 & 3.811 & 2.397 & 0.022 \\
Leverage & -33.369 & -3.602 & 0.000 & -13.408 & -2.482 & 0.018 \\
\hline
\end{tabular}

Table 9 shows that compensation (for both levels of FReturn) is not significant ( $\operatorname{sig}=0.156$ and 0.265 ). This suggests that compensation is not positively related to future market performance for both high and low levels of R\&D. Since both are insignificant, there is no difference in the association between compensation and future market performance at different levels. Therefore, risk preference does not moderate the association between compensation and future market performance. This result fails to support the third hypothesis.

Table 10 shows that compensation for high $R \& D$ and low $R \& D$ are not significant (sig=0.520 and 0.125). This also suggests that, like the future market performance results, risk preference does not moderate the association between compensation and future performance. Therefore, the third hypothesis is unsupported. The result does not confirm the BAM.

When used as control variables, the total assets and leverage did not show a significant impact on the "R\&D: High" and "R\&D: Low" for future market performance (return). Total assets showed significant results in "R\&D: Low" for the performance of accounting, while the leverage variable was not significant. Split sample in "R\&D: 
High" for the accounting performance measurement shows that both control variables are not significant. Risk preference does not strengthen or weaken the relationship between compensation and the company's future performance using either market performance measurement or accounting performance. In Indonesia, especially for manufacturing companies, managers select the risk preference policy in setting $\mathrm{R} \& \mathrm{D}$ (risk takers), which does not align the preferences of managers to those of shareholders. The results suggest a possibility that managers focus only on performance in the short term. Cash compensation is synonymous with short-term performance, while stock compensation is associated with the long-term. Companies carry out R\&D just because there is a demand for their products. Only a few firms in Indonesia carry out R\&D in regular and sustained periods. The risk-taker condition does not imply that compensation will motivate the company's future performance. The results contradict studies conducted by Nyberg et al. (2010), which state that a strong financial harmony will be followed by the alignment of the preferences and actions. However, this study is in line with the results of Gray \& Cannella (1997), which showed that compensation arrangements are not necessarily linked to the performance neither do they align the risk preferences of managers and shareholders.

\subsection{Additional Test}

The purpose of the additional test was to provide empirical evidence of the relationship between top management compensation and the company's performance in the future based on the companies' performance category (Murphy, 1998). Table 11 presents the results of additional tests as follows:

Table 11

Result of Additional Test

\begin{tabular}{|c|c|c|c|c|c|c|}
\hline \multirow[t]{2}{*}{ Variable } & \multicolumn{3}{|c|}{ FReturn } & \multicolumn{3}{|c|}{ FROA } \\
\hline & Coef & $\mathbf{t}$ & Sig & Coef & $\mathbf{t}$ & Sig \\
\hline & & & eat & & & \\
\hline Ln Compensation & 0.005 & 0.297 & $\begin{array}{l}0.767 \\
\text { ood }\end{array}$ & 1.445 & 1.792 & 0.076 \\
\hline Ln_Compensation & 0.009 & 0.734 & $\begin{array}{l}0.464 \\
\text { oor }\end{array}$ & 0.813 & 2.868 & 0.005 \\
\hline Ln_Compensation & -0.031 & -0.560 & $\overline{0.576}$ & -0.283 & -0.602 & 0.548 \\
\hline
\end{tabular}


Further test results show that the provision of compensation will motivate managers to improve only the future accounting performance of the company in the good category. Compensation is not related to market performance in all of the company categories. This study supports the research conducted by Medina (2010) on companies in the United States, which showed that companies in the good category show a relationship between future compensation and accounting performance. Managers who work in a company that is in the good category through the provision of compensation, are required to provide higher accounting performance.

\section{Conclusion, Limitation, and Recommendation}

This study supports the hypothesis of the relationship between a company's performance, which is measured based on accounting performance (ROA) and the top management compensation. However, these results do not support the relationship between market performances (return) and top management compensation. The test results demonstrate that managers will receive substantial compensation when higher empirical accounting performances are achieved.

Compensation as a tool to motivate the company's future performance in the future is supported only on accounting performance (ROA), but not for market performance. The higher the compensation received by the manager, the more likely it is that they will be motivated to produce stronger accounting performance in the future. Compensation is based more strongly on accounting performance, whereas it also has an impact on future accounting performance. This does not apply to market performance. Market performance is not affected by compensation. R\&D decision making (risk preference) in Indonesian manufacturing companies has not been proven to strengthen or weaken the relationship between top management compensation and the company's future performance. Although financial alignment occurs, it is not necessarily followed by the alignment of the preferences and management actions.

Additional tests also prove that the compensation will motivate managers to increase accounting performance in the future only in the category of good company. 
Performance measurement based on the market performance for the great, good, and poor company, and it shows that the compensation does not motivate managers to work better.

Companies in Indonesia do not disclose details of their based on their components (salaries, allowances, and bonuses). Disclosure of compensation based on its components can explain in greater detail, according to research conducted by Banker et al. (2013). Besides that, future research considers the subjective aspects of the individual (Tjahjono, 2011). This study has limitations in performance measurement, which are based on accounting performance and market performance. This study only uses return for the market performance and ROA for accounting performance. Various proxies for measuring the performance of both market performance and the accounting performance should be considered in future studies. Results on the relationship between market performance and top management compensation and the relationship between compensation and future market performance show no significant relations. It is important to study this relationship in greater depth to gain a more comprehensive explanation, especially related to market performance.

\section{References}

Aaron, J. R., Harris, M. L., Mcdowell, W. C., \& Cline, B. N. (2014). Optimal Ceo Incentive Contracts: A Prospect Theory Explanation. Journal of Business Strategies, 31, 336357.

Banker, R. D., Huang, M. N., \& Plehn-Dujowich, J. M. (2013). The Relation between CEO Compensation and Past Performance. The Accounting Review, 88(1), 1-30. doi:10.2308/accr-50274

Barkema, H. ., \& Gomes-Mejia, L. (1998). Managerial Compensation and Firm Performance : A General Research Framework. Academy of Management Journal, 41, 135-145.

Belanes, A., \& Hachana, R. (2010). Corporate Governance and Managerial Risk-Taking in Tunisia: An Agency Perspective. Journal of Global Business Administration, 2, 53-70.

Cheng, S. (2004). R\&D Expenditures and CEO Compensation. The Accounting Review, 79(2), 305-328. 
Conyon, M. J., \& He, L. (2012). CEO Compensation and Corporate Governance in China. Corporate Governance: An International Review, 20(6), 575-592. doi:10.1111/j.14678683.2012.00935.x

Cordeiro, J. J., Veliyath, R., \& Romal, J. B. (2007). Moderators of the Relationship Between Director Stock-Based Compensation and Firm Performance. Compilation, 15(6), 13841393. doi:10.1111/j.1467-8683.2007.00652.x

Devers, C. E., Cannella, A. A., Reilly, G. P., \& Yoder, M. E. (2007). Executive Compensation : A Multidisciplinary Review of Recent Developments. Journal of Management, 33, 1016-1072. doi:10.1177/0149206307308588

Devers, C. E., Holcomb, R. M., \& Cannella, A. A. (2006). Inside the Black Box: The Contrasting Effects of TMT Long-Term Incentives on Interest Alignment. Academy of Management Best Conference Paper, 1-7.

Devers, C. E., Mcnamara, G., Wiseman, R. M., \& Arrfelt, M. (2008). Moving Closer to the Action: Examining Compensation Design Effects on Firm Risk. Organization Science, 19(4), 548-566.

Doucouliagos, H., Haman, J., \& Askary, S. (2007). Directors' Remuneration and Performance in Australian Banking. Compilation, 15(6), 1363-1383. doi:10.1111/j.14678683.2007.00651.x

Fama, E. F. (1980). Agency Problems and the Theory of the Firm. Journal of Political Economy, 88(2), 288-307.

Ganguli, S. K., \& Agrawal, S. (2015). Ownership Structure and Firm Performance: An Empirical Study on Listed Mid-Cap Indian Companies. The IUP Journal of Applied Finance, 15(12), 37-52.

Ghosh, A., \& Aggarwal, R. (2011). Directors remuneration various issues relating to firm performance.

Gigliotti, M. (2013). The compensation of top managers and the performance of Italian firms. The International Journal of Human Resource Management, 24(4), 889-903. doi:10.1080/09585192.2012.702317

Grace, E. (2004). Contracting Incentives and Compensation for Property-Liability Insurer Executive. The Journal of Risk and Insurance, 71(2), 285-307.

Gray, S. R., \& Cannella, A. A. (1997). The Role of Risk in Executive Compensation. Journal of Management. 
Guay, W. R. (1999). The sensitivity of CEO wealth to equity risk: an analysis of the magnitude and determinants. Journal of Financial Economics, 53(1), 43-71. doi:10.1016/S0304405X(99)00016-1

Gunasekaragea, A., \& Wilkinson, M. (2002). CEO Compensation and Firm Performance: A New Zealand Investigation. International Journal of Business Studies, 10, 45-60.

Hambrick, D. C. (2007). Editor's Forum Upper Echelons Theory: An Update. Academy of Management Review, 32(2), 334-343.

Hambrick, D. C., \& Mason, P. A. (1984). Upper Echelons: The Organization as a Reflection of Its Top Managers. The Academy of Management Review, 9(2), 193-206. doi: $10.2307 / 258434$

Haniffa, R., \& Hudaib, M. (2006). Corporate Governance Structure and Performance of Malaysian Listed Companies. Journal of Business Finance \& Accounting, 33(7-8), 1034-1062. doi:10.1111/j.1468-5957.2006.00594.x

Haron, H., \& Akhtaruddin, M. (2013). Determinants of Directors' Remuneration in Malaysian Public Listed Companies. Indian Journal of Corporate Governance, 6(2), 17-42.

Ibrahim, H., \& Samad, F. A. (2011). Corporate Governance Mechanisms and Performance of Public-Listed Family-Ownership in Malaysia. International Journal of Economics and Finance, 3(1), 105-115.

Jensen, M. C., \& Murphy, K. J. (1990a). Performance Pay and Top-Management Incentives. Journal of Political Economy, 98(2), 225. doi:10.1086/261677

Jensen, M. C., \& Murphy, K. J. (1990b). Performance Pay and Top-Management Incentives. Journal of Political Economy, 98(2), 225-264.

Kapopoulos, P., \& Lazaretou, S. (2007). Corporate Ownership Structure and Firm Performance: evidence from Greek Firms. Journal Compilation, 15(2), 144-158. doi:10.1111/j.14678683.2007.00551.x

Kato, T., Kim, W., \& Lee, J. H. (2007). Executive Compensation, Firm Performance, and Chaebols in Korea: Evidence from New Panel Data. Pacific-Basin Finance Journal, 15(1), 36-55. doi:10.1016/j.pacfin.2006.03.004

Kato, T., \& Kubo, K. (2006). CEO compensation and firm performance in Japan: Evidence from new panel data on individual CEO pay. Journal of the Japanese and International Economies, 20(1), 1-19. doi:10.1016/j.jjie.2004.05.003

Lewellen, W., Loderer, C., Martin, K., \& Blum, G. (1992). Executive Compensation and the Performance of the Firm. Managerial and Decision Economics, 13, 65-74. 
Medina, S. (2010). Analisis Pegaruh Kompensasi Eksekutif terhadap Kinerja Perusahaan: Kasus pada Good and Great Companies. Tesis Pada Program Magister Sains Dan Doctor FE $U G M$.

Merhebi, R., Pattenden, K., Swan, P. L., \& Zhou, X. (2006). Australian chief executive officer remuneration: pay and performance. Accounting and Finance, 46, 481-497.

Miller, K. D., \& Bromiley, P. (1990). Strategic Risk and Corporate Performance: an Analysis of Alternative Risk Measures. Academy of Management Journal, 33(4), 756-779. doi: $10.2307 / 256289$

Murphy, K. J. (1998). Executive Compensation. Marshall School of Business University of Southern California, (April).

Naranjo-Gil, D., Cuevas-Rodriguez, G., Lopez-Cabrales, A., \& Sanchez, J. M. (2012). The Effects of Incentive System and Cognitive Orientation on Teams' Performance. Behavioral Research in Accounting, 24(2), 177-191. doi:10.2308/bria-50098

Nguyen, T. Q. (2012). Two Essays on Executive Pay and Firm Performance. Disertasi Universitas Ekonomi Nasional Vietnam.

Nyberg, A. J., Fulmer, I. S., Gerhart, B., \& Carpenter, M. A. (2010). Agency Theory Revisited: CEO Return and Shareholder Interest Alignment. Academy of Management Journal, 53(5), 1029-1049.

Parthasarathy, A., Menon, K., \& Bhattacherjee, D. (2006). Executive Compensation, Firm Performance, and Corporate Governance : An Empirical Analysis. Indian Institute of Management Calcutta.

Rost, K., \& Osteroh, M. (2009). Management Fashion Pay-for-Performance for CEOs. Schmalenbachs Business Review, 119-150.

Sawers, K., Wright, A., \& Zamora, V. (2011). Does Greater Risk-Bearing in Stock Option Compensation Reduce the Influence of Problem Framing On Managerial Risk-Taking Behavior? Behavioral Research in Accounting, 23(1), 185-201. doi:10.2308/bria.2011.23.1.185

Shan, Y. G. \& McIver, R. P. (2011). Corporate Governance Mechanisms and Financial Performance in China: Panel Data Evidence on Listed non Financial Companies. Asia Pacific Business Review, 17(3), 301-324. doi:10.1080/13602380903522325

Sitkin, S. B., \& Pablo, A. L. (1992). Reconceptualizing the Determinants of Risk Behavior. Academy of Management Review, 17(1), 9-38.

Sprinkle, G. B. (2000). The Effect of Incentive Contracts on Learning and Performance. The Accounting Review, 75(3), 299-326. 
Sugiri, S., Febrianto, R., \& Kresnawati, E. (2016). Sticky Cost Behavior of Bank's Executive Compensation in Four South East Asian countries. Journal of Economics, Business, and Accountancy Ventura, 19(3), 363-376. doi:10.14414/jebav.v19i3.771

Sun, F., Wei, X., \& Huang, X. (2013). CEO compensation and firm performance: Evidence from the US property and liability insurance industry. Review of Accounting and Finance, 12(3), 252-267. doi:10.1108/RAF-Jan-2012-0006

Tjahjono, H. . (2011). The Configuration among Social Capital, Distributive and Procedural Justice, and its Consequences to Individual Satisfaction. International Journal of Information and Management Sciences, 87-103.

Wahla, K., Shah, S. Z., \& Hussain, Z. (2012). Impact of Ownership Structure on Firm Performance Evidence from Non-Financial Listed Companies at Karachi Stock Exchange. International Research Journal of Finance and Economics, (84).

Wiseman, R. M., \& Gomez-Mejia, L. R. (1998). A Behavioral Agency Model Of Managerial Risk Taking. Academy of Management Review, 23(1), 133-153.

Wiyanti, S. (2013). BI Kaji Pemberian Remunerasi untuk Pegawai Bank. Merdeka. Retrieved from https://www.merdeka.com/uang/bi-kaji-pemberian-remunerasi-untuk-pegawaibank.html

Xiao, Z., He, R., Lin, Z., \& Elkins, H. (2013). CEO compensation in China Accounting Performance, Corporate Governance, and the gender gap. Nankai Business Review International, 4(4), 309-328. doi:10.1108/NBRI-09-2013-0032

Yang, F., Dolar, B., \& Mo, L. (2014). CEO Compensation and Firm Performance : Did the 20072008 Financial Crisis Matter? Journal of Accounting and Finance, 14(1), 137-147. 
The Indonesian Journal of Accounting Research - May, Vol. 22, No.2, 2019

intentionally blank 